\title{
Toward a Better Understanding of Trade Balance Trends: The Cost-Price Puzzle
}

The key to the problem of estimating long-run [import] elasticity lies, $I$ feel sure, in the supply side of the supply-demand picture.

Even to approximate it will probably require a close survey of the American economy, with a view to ascertaining the extent of each industry's vulnerability to price competition from abroad or, conversely, its ability to raid the foreigner's share of our domestic market.-Arnold C. Harberger ${ }^{1}$

THE INADEQUACIES of the time series models of import and export behavior have long been apparent. To justify the omission of the supply side, the typical Keynesian function has been based upon the assumptions of imperfect substitution and infinite supply elasticities of importables both at home and abroad. While a cyclical variable is sometimes introduced to capture nonprice rationing effects such as changes in delivery times (as well as the particular cyclical composition of demand), the most common specification makes the demand for imports (exports) a function of their relative price and an activity variable.

Although such equations have been able to fit historical data with a

Note: I am grateful to the participants of the Brookings panel for comments on an early draft. I had helpful conversations with Lawrence B. Krause, James C. Riedel, and Walter S. Salant. I thank Arthur C. Kupferman and Karen S. Ostrow for research assistance, Richard B. Thomas and Joseph Tu for computer assistance, and Michael C. Deppler of the International Monetary Fund for supplying me with data.

1. Arnold C. Harberger, "A Structural Approach to the Problem of Import Demand," American Economic Review, vol. 43 (May 1953, Papers and Proceedings, 1952), pp. 157-58. 
reasonable degree of accuracy, their coefficients have not been particularly stable. ${ }^{2}$ Yet for the United States, the qualitative implications of a pair of such equations have proved to be essentially correct for almost thirty years. In a seminal paper, Houthakker and Magee fitted conventional import and export functions to annual data from the 1951-66 period and estimated an income elasticity for U.S. imports of 1.5 , which was considerably greater than the estimated elasticity of 1.0 on foreign income in the U.S. export equation. ${ }^{3}$ These estimates of import demand elasticities imply ceteris paribus that equal rates of growth in the United States and in the rest of the world will mean a declining U.S. trade balance. Assuming trade is initially balanced, U.S. growth would have to be onethird less than growth abroad to maintain balance." This "HouthakkerMagee effect" stems mainly from trade in manufactured goods. A pair of equations for manufactured goods indicates foreign and U.S. long-run income elasticities for U.S. exports and imports of manufactured goods are 1.3 and 3.1, respectively. ${ }^{5}$ Given the annual growth rates in the U.S. potential GNP of 3.7 percent (for the 1960-77 period) and in the potential output for the "rest of the world" of 6.0 percent, the coefficients imply annual growth rates of 11.5 percent for U.S. manufactured goods imports but only 7.8 percent for U.S. manufactured goods exports.

As the quotation from Harberger above indicates, economists have long been concerned about the purely demand-side orientation of these trade equations. Domestically produced commodities are likely to be close substitutes for imports of many producer goods, such as chemicals and metals, and consumer goods, such as clothing and shoes. In these cases the coefficient on the income term in an import function will actually be an excess demand elasticity derived from the home demand and supply

2. For a discussion of the stability of U.S. import and export functions see Peter Hooper, "The Stability of Income and Price Elasticities in U.S. Trade, 1957-1977," International Finance Discussion Paper 119 (Board of Governors of the Federal Reserve System, June 1978). See also Robert M. Stern, Christopher F. Baum, and Mark N. Greene, "Evidence on Structural Change in the Demand for Aggregate U.S. Imports and Exports," Journal of Political Economy, vol. 87 (February 1979), pp. 179-92.

3. H. S. Houthakker and Stephen P. Magee, "Income and Price Elasticities in World Trade," Review of Economics and Statistics, vol. 51 (May 1969), pp. 111-25.

4. If growth exceeded this rate, the terms of trade would have to decline to maintain balance.

5. See Robert Z. Lawrence, "An Analysis of the 1977 U.S. Trade Deficit," BPEA, 1:1978, p. 174 . 
functions. ${ }^{6}$ The coefficient on income in the conventional import function for such undifferentiated products is better expressed as a reduced-form parameter that picks up the combined effects of domestic supply and demand rather than as an income elasticity of demand in the sense that it is used in consumer theory. ${ }^{7}$ And in such cases the relative price term is likely to be an estimate of the price elasticity between importables and all other home goods. For standardized products, relative cost schedules, rather than relative prices, will determine trade performance. If the foreign supply schedule for importables shifts downward over time, foreigners will increase their shares of the domestic market at any given price. The conventional import specification, which fails to include costs in the equation, will pick up this effect in the income coefficient.

In the case in which imports are imperfect substitutes, there are also sound reasons to suspect that the coefficient on the income variable is not a pure income-demand elasticity. In theory, given preferences and information, only income and relative prices affect demand. But when a foreign producer penetrates a new market, he is likely to invest substantial resources in familiarizing the market with his product. It will take time to establish a service capability, acquire a reputation, and pry consumers loose from their old familiar habits. These effects will not be reflected in price, but they should shift the demand curve. It is reasonable to suspect that the penetration pattern will take the form of the familiar logistic or S-shaped curve that characterizes most adoption processes. The likely phases are a struggle to obtain a foothold, a period of rapid growth, and a tapering off toward a long-run trend share. ${ }^{8}$ During this penetration

6. If $M(Y)=D(Y)-S(Y)$, where $M$ is the quantity of imports demanded, $D$ is the home demand for importables, and $S$ is the home supply, this implies that $e_{m y}=(D / M) e_{d y}-(S / M) e_{s y}$, where $e_{m y}$ is the import income elasticity; $e_{d y}$, the income elasticity of demand; and $e_{s y}$, the income elasticity of supply.

7. For a discussion of this distinction and for the derivation of the equation for the import-income elasticity see Stephen P. Magee, "Prices, Incomes, and Foreign Trade," in Peter B. Kenen, ed., International Trade and Finance: Frontiers for Research (Cambridge University Press, 1975), pp. 188-92.

8. The entry of foreign automobiles into the United States is a prime example. Non-Canadian imports had a minuscule share of the U.S. automobile market in the 1950s. The penetration by Volkswagen made a small impression, and by 1964 the share of foreign automobiles in U.S. purchases was 6.5 percent. In the late $1960 \mathrm{~s}$ there was a period of rapid penetration, however, and by 1970 the foreign share had shot up to 16 percent. Yet in 1975, it was only 16.4 percent and in 1977, 17.2 percent. See United States International Trade Commission, Automotive Trade Statistics, 1964-77, series B: Passenger Automobiles, Publication 913 (USITC, 1978). 
process, foreign producers may be constrained by capacity and may prefer to ration in order to build goodwill rather than charge what the market will bear. Once these producers gain a foothold in the market, they may well raise prices. During a period of rapid penetration, the econometric estimates of the price elasticity of demand are unlikely to detect these developments and will therefore not indicate true long-run coefficients. If a strong trend in import penetration occurs, the coefficient on the income term, which itself has an upward trend, is likely to be biased upward.

The conventional trade equations would also mislead in the case when the entry of foreign producers into the domestic market drives the prices of domestic substitutes below the domestic firms' long-run average costs. Short-run domestic prices might decline, but as firms were driven from the market their shares would be taken over by new foreign entrants. Again the income coefficient might pick up this effect.

The neglect of the supply side could well lead to erroneous inferences. As the experiences of Japan and Germany illustrate (and the pure theory of international trade reminds us), growth that is biased toward an expansion of exportables at given terms of trade could well lead to a trade surplus rather than a deficit. Only by making the sectoral composition of growth endogenous will it be possible to separate supply from demand.

The foregoing suggests that trade equations should be specified to account explicitly for the supply side. An ideal model would use the determinants of costs in explaining trade behavior. By taking account of longrun costs, it would be possible to distinguish the price declines that represent improvements in productivity and outward shifts in supply schedules from those that represent reduced profitability resulting from inward shifts in demand.

As a preliminary step toward undertaking such a model, the appropriate level of disaggregation must be determined. Common practice has explained the movement in manufactured goods prices in international trade by using data for unit costs in the manufacturing sector. In this paper, I present evidence that brings this practice into question. Inferences about relative trade performance and profitability based upon manufacturing sector data are likely to be misleading. In certain foreign countries, costs in export industries have risen considerably less rapidly than costs in their manufacturing sectors in general. As a result of this "dualism," overall manufacturing costs provide a misleading indicator of true export costs. In other countries, most notably the United States, 
there is little evidence of a similar dualism; costs in export industries seem to have run roughly parallel to those in manufacturing as a whole. From this investigation, I am able to draw an important conclusion. If past trends continue, costs in U.S. manufacturing must rise less rapidly than those in manufacturing abroad for U.S. products to remain competitive in world markets.

\section{The Cost-Price Puzzle}

Table 1 provides time series on indexes of unit labor costs in manufacturing in the major industrial countries, expressed in U.S. dollars. The data are surprising, particularly because the United States has fared poorly in manufactured goods trade, while Japan, Germany, and Italy have done well. During the 1960-77 period, unit labor costs in U.S. manufacturing rose at an average annual rate of 3.3 percent, while those in Japan, Germany, and Italy rose at rates of 8.4, 8.2, and 6.8 percent, respectively. In recent periods, this disparity is even greater. From 1970 to 1977, unit labor costs rose 5.3 percent annually in the United States and 16.4, 12.8, and 10.1 percent in Japan, Germany, and Italy, respectively.

These disparities in relative unit costs could simply indicate that the absolute costs (and prices) abroad were initially much lower than those in the United States. But if this explanation were valid, one would expect to see relative export prices changing in a similar fashion. Table 2 indicates that they have not.

U.S. export prices closely paralleled both standard unit labor costs and total unit costs until the price hike of the Organization of Petroleum Exporting Countries in 1973 raised the relative price of materials inputs, and thus the margin between prices and value added in manufacturing. By contrast, the ratio of export prices to either standard unit labor costs or total unit costs fell persistently through 1973 in Germany, Italy, and Japan. For these countries, smaller but substantial downward trends are also evident in the ratios of export prices to value added in manufacturing and in the ratios of export prices to wholesale prices for finished manufactured goods.

To explore the disparity between export prices of manufactured goods and costs in manufacturing, I estimated a number of export price equations that relate export prices to variables commonly used to explain 


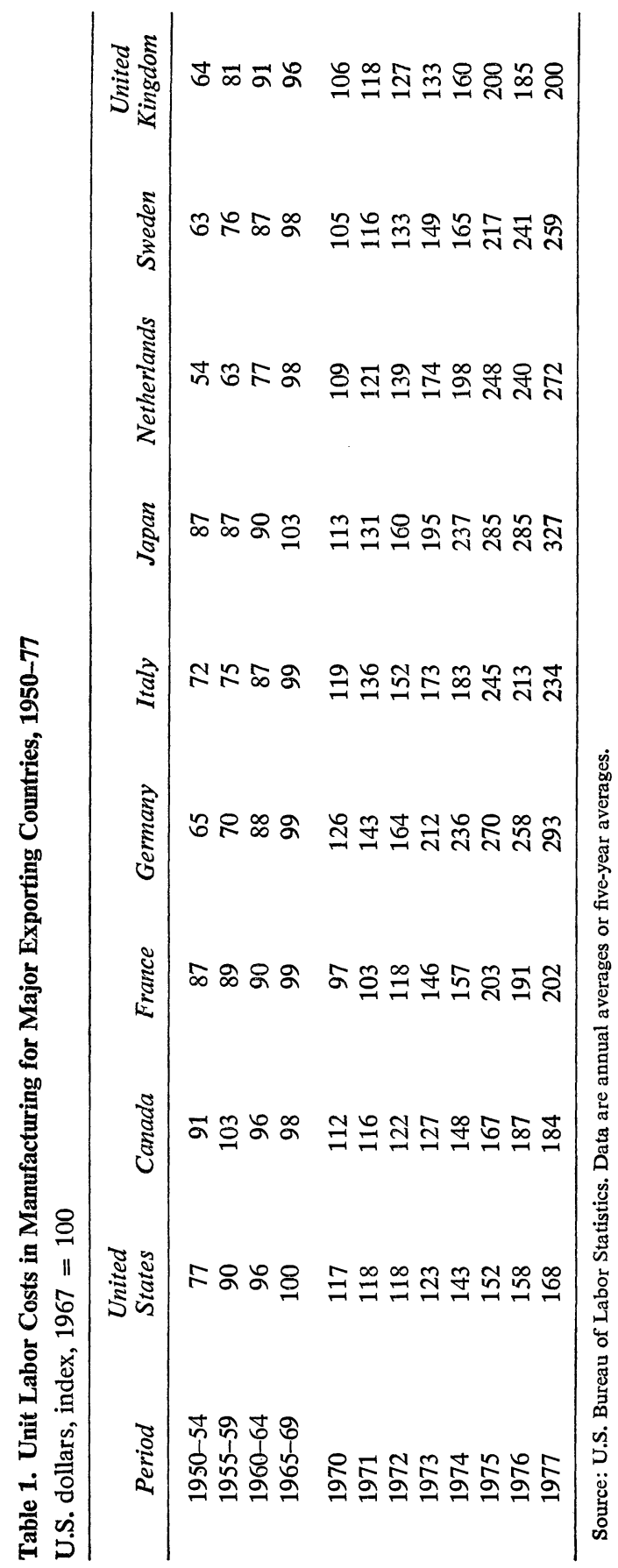




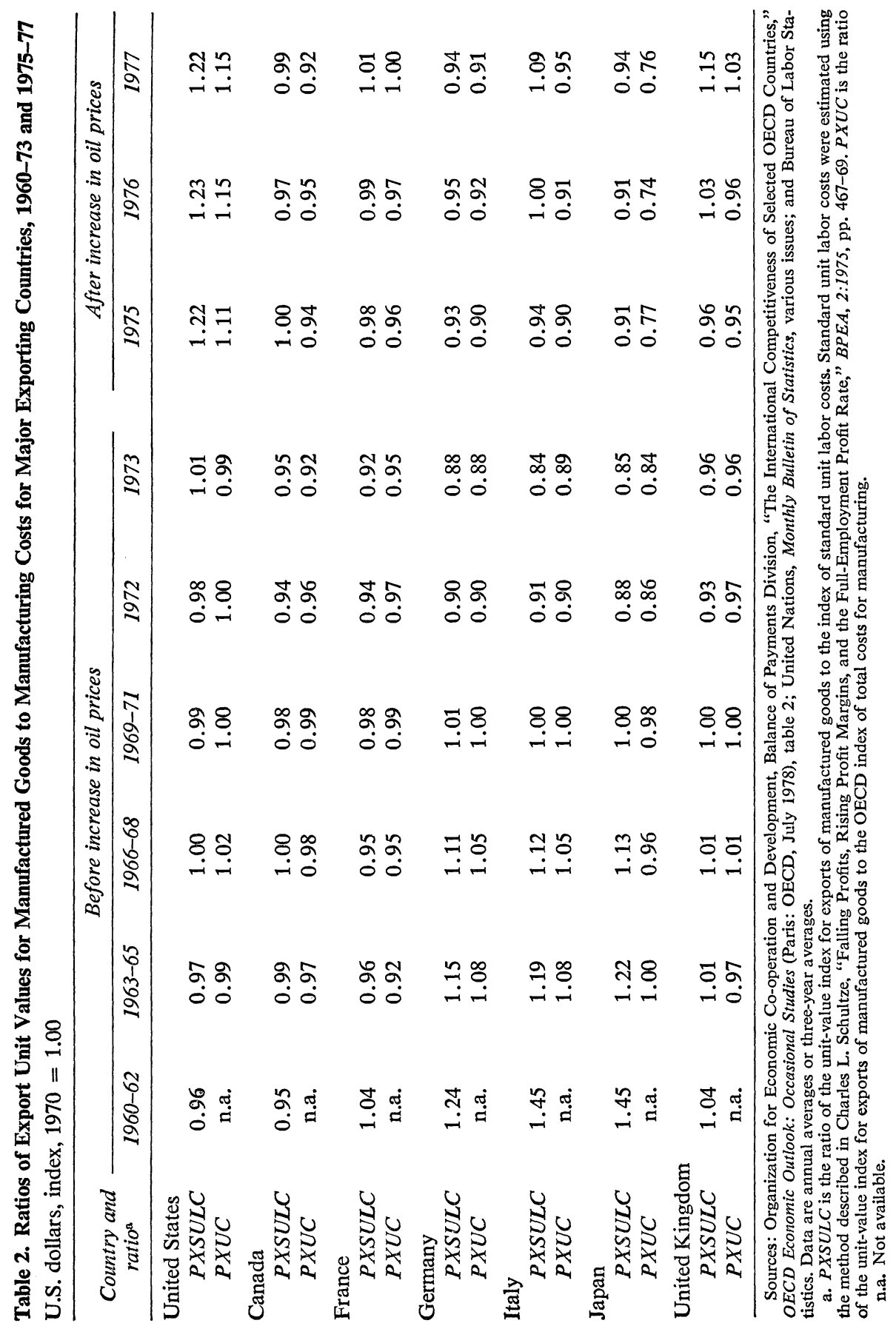


them. The conventional structural interpretation given to the equation for export prices, $P$, is that of a markup model. Firms are assumed to set export prices by "marking up" their unit labor costs (corrected for cyclical productivity), $S U L C$, and unit materials costs, $U M C$; that is,

$$
P=k(S U L C)+k(U M C) .
$$

The markup, $k$, is in turn assumed to depend upon competitors' prices, $P C$, and capacity utilization at home, $G^{d}$, and abroad, $G^{a} \cdot{ }^{9}$ This leads to an estimation equation in logarithmic form:

$$
\begin{aligned}
\log P= & a_{0}+a_{1} \log S U L C+a_{2} \log U M C+a_{3} \log P C \\
& +a_{4} \log G^{d}+a_{5} \log G^{a} .
\end{aligned}
$$

Estimating this equation alone implies that $S U L C, U M C$, and $P C$ are exogenous. In fact, theory suggests that these variables are more properly considered as endogenous to a more fully specified equation system.

An alternative formulation takes domestic prices, $D P$, as exogenous and assumes that export prices are more strongly influenced by competitors' prices and have different cyclical movements:

$$
\log P=b_{0}+b_{1} \log D P+b_{2} \log P C+b_{3} \log G^{a}+b_{4} \log G^{d} .
$$

In table 3 several equations for export price, based on formulations such as these, are reported for each major industrial country. The aim here is not to select the best equation, but rather to look for unexplained trends in export prices. Some of the equations have estimated coefficients that render them of dubious merit. In particular, the coefficients on the nominal variables sum to more than unity. But together they convey the strong impression that in Germany, Italy, Japan, and, to a lesser degree, France, unit values for exports have shown significant downward movements relative to the explanatory variables. ${ }^{10}$ Adding a time trend to the equations for these countries leads to a significant negative coefficient on

9. For a more complete presentation, see Peter B. Clark, "The Effects of Recent Exchange Rate Changes on the U.S. Trade Balance," in Peter B. Clark, Dennis E. Logue, and Richard James Sweeney, eds., The Effects of Exchange Rate Adjustments, proceedings of a conference sponsored by OASIA Research, Department of the Treasury (Government Printing Office, 1977), pp. 201-36.

10. In the case of Japan, the use of the export price index as a dependent variable gave results similar to those of the unit value index for manufactured goods. 
the trend term and an improvement in the estimated coefficients of the equations. On the other hand, for the United Kingdom, Canada, and the United States, the trend term is generally insignificant.

The equations do reveal some further interesting features of pricing in export markets. The state of the cycle in the rest of the world does not influence export pricing, and only in the case of Japan is the cycle at home a significant factor. (As a result, only for Japan do the equations use the ratio of actual to potential manufacturing output as an independent variable.) Competitors' prices, $R O W P X$, play a major role in determination of export prices, although the noticeable reduction in some of the $R O W P X$ coefficients when wholesale and materials prices are used as explanatory variables suggests that part of the competitive effect could actually stem from a common rise in the prices of global raw materials.

Without the dummy variable for the price control period, the U.S. equations exhibit large residuals in 1972 and 1973. Because controls apparently held down export prices, the influence of devaluation on U.S. export prices during this period is underestimated. ${ }^{11}$ This strong effect on export prices from controls is further evidence that U.S. export prices closely reflect the behavior of U.S. domestic prices.

\section{EXPLAINING THE TRENDS}

Several explanations might be offered for the strong negative trends in export prices relative to other prices in Japan, Germany, Italy, and France. One explanation might be measurement error. The weaknesses of unit values as a price measure are well known. Yet the series on export prices, which indicate strong competitive improvements for these countries (or smaller competitive declines), are more consistent with their actual trade performance than are the cost data, which suggest large competitive losses. The weakness could lie in the data on unit labor costs. Although the U.S. Bureau of Labor Statistics strives to ensure that these data are comparable across countries, it cautions: "published average

11. In the state-of-the-art paper on the effects of the exchange rate changes in 1971-73 on the U.S. trade balance, Clark obtains a statistically significant negative effect of dollar devaluation on U.S. dollar export prices, yet he dismisses it as a statistical fluke. See his "The Effects of Recent Exchange Rate Changes," p. 213, note 17. 


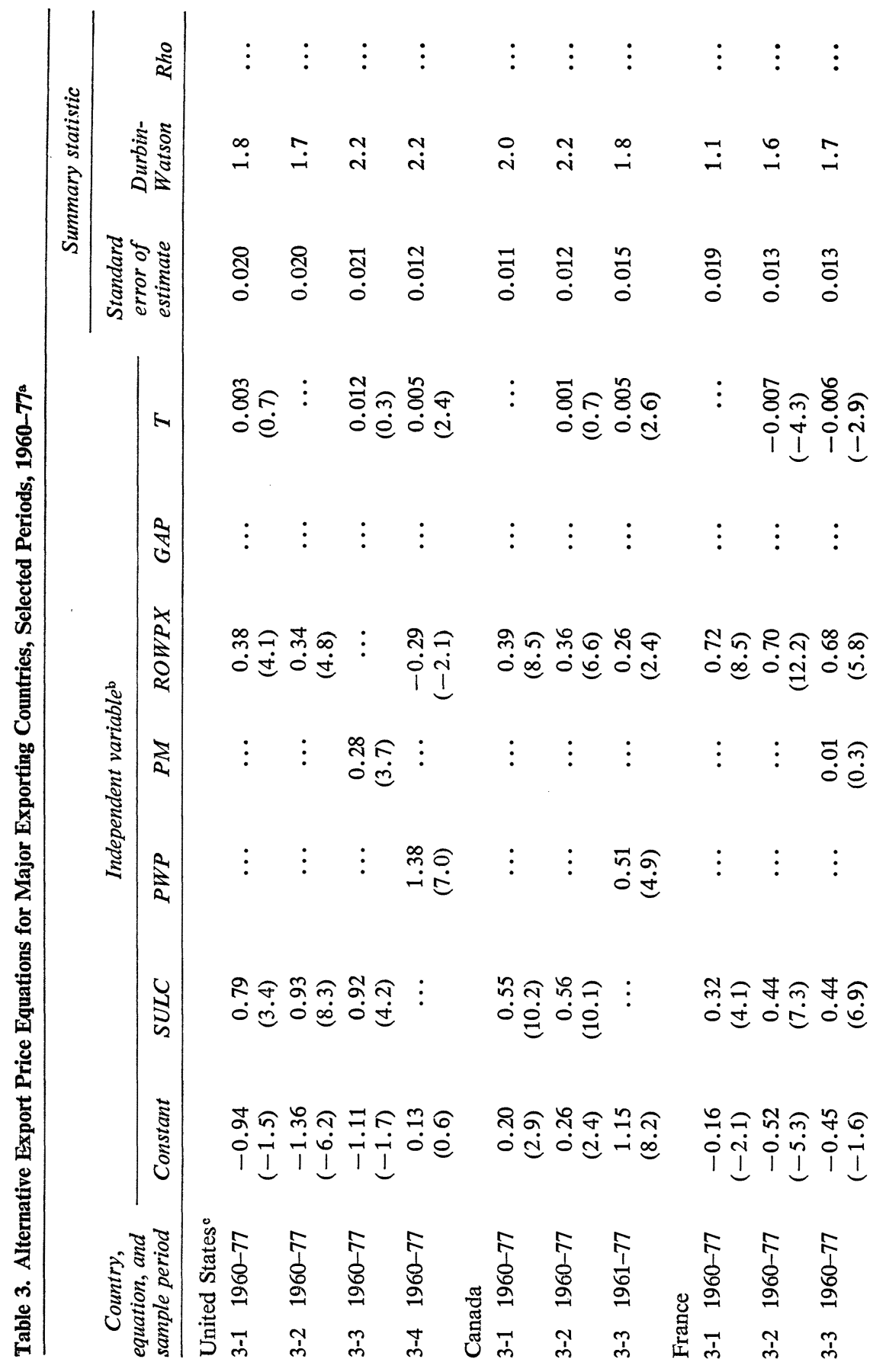




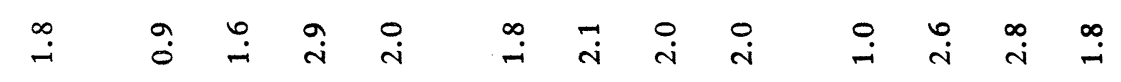

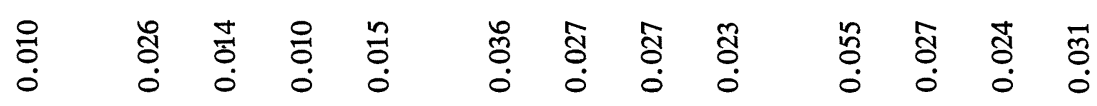

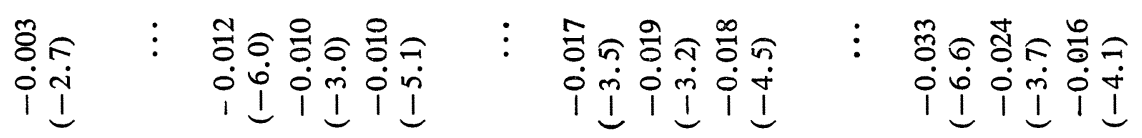

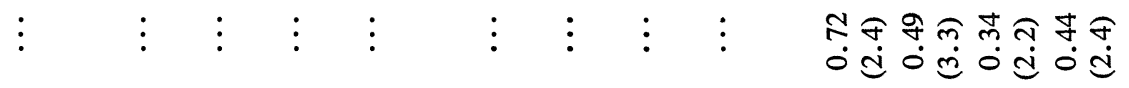

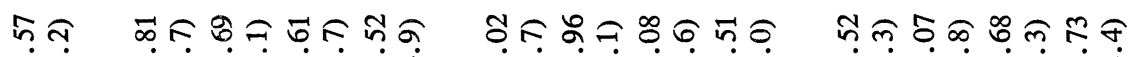

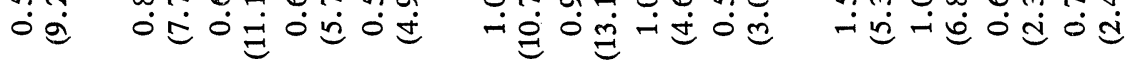

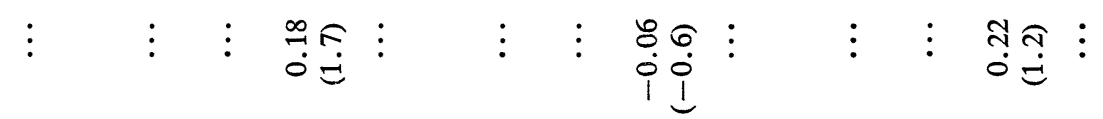

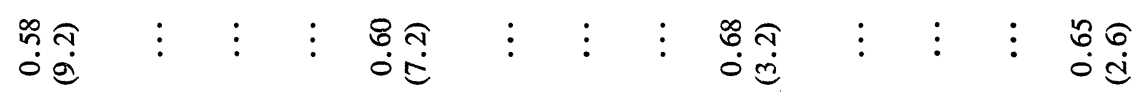

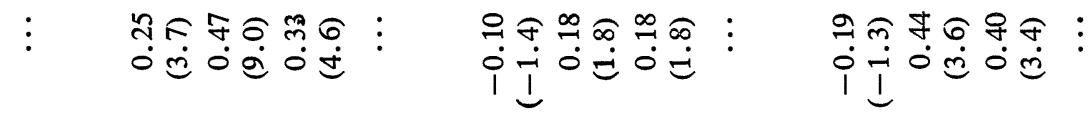

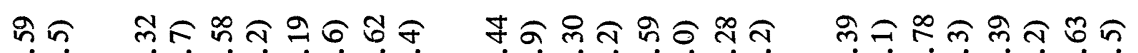

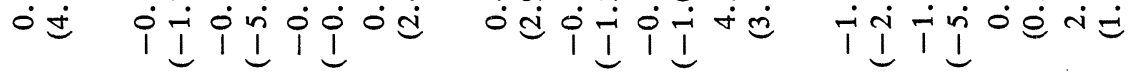

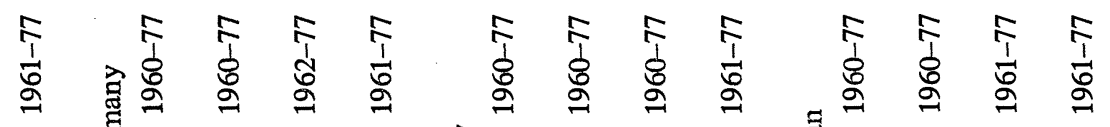

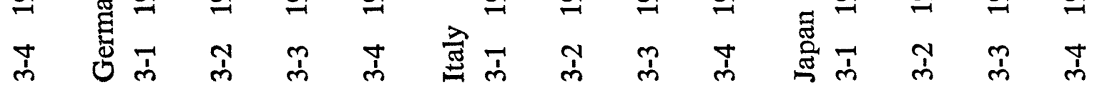




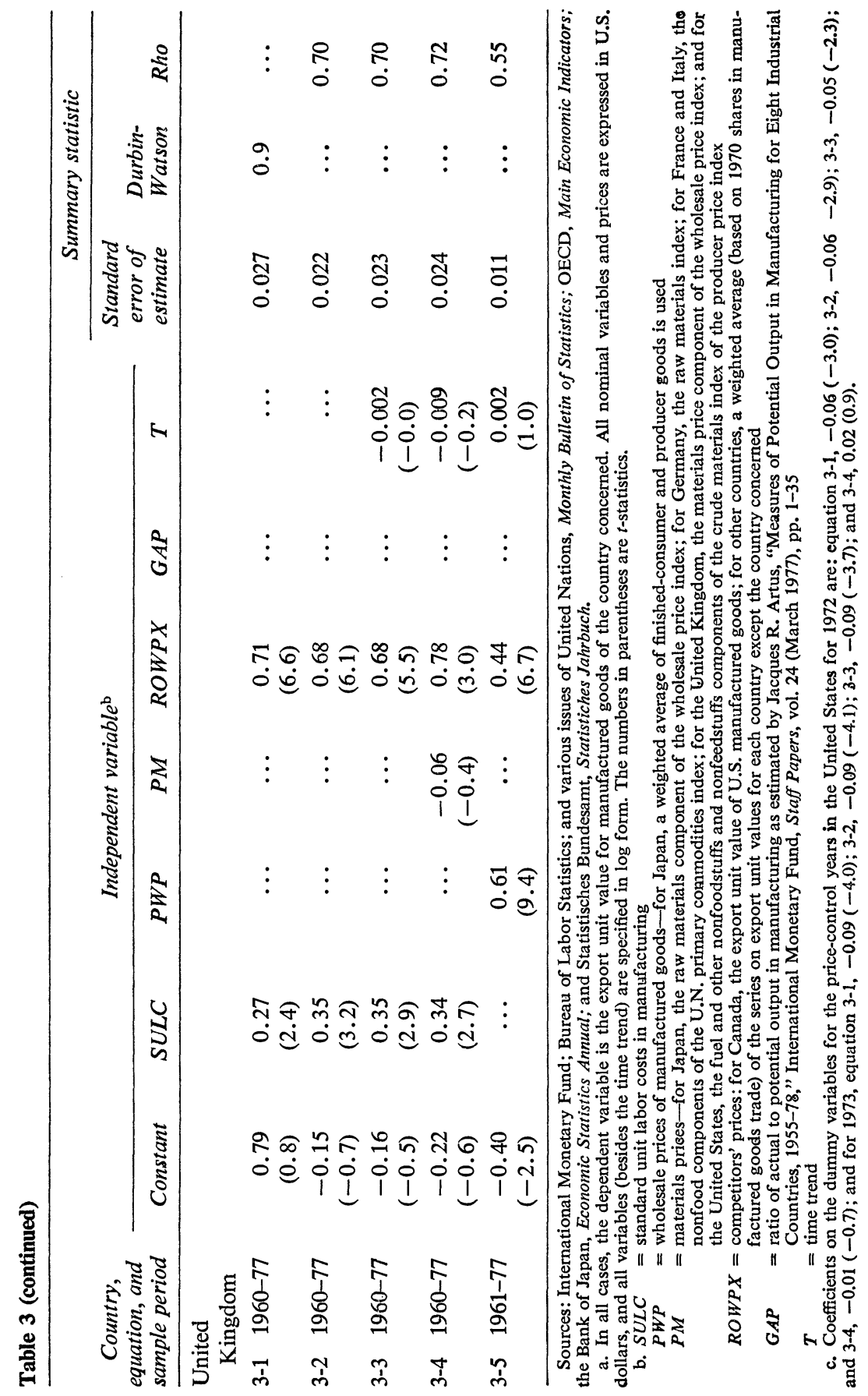


hourly earnings may not include the same items of labor compensation in each country." ${ }^{2}$ But because the trends persist with alternative equations when other prices replace costs, it is difficult to dismiss them simply as statistical aberrations. ${ }^{13}$

If the data are accepted, several alternative hypotheses can be considered. The first is that firms manufacturing for export in these countries have been prepared to cut their profit margins continuously. This explanation is credible as a short-run response to competitive pressures, but it cannot explain trends over a seventeen-year period. The coefficients in the Japanese, Italian, and German equations indicate that export prices fell relative to costs by between 1 and 3 percent a year. Profits as a proportion of value added would have had to be implausibly large initially to permit such declines. In addition, the equations suggest that this reduction in export prices occurred in excess of that required by competitive pressures. There is evidence that German and Japanese export firms have had to reduce their profit margins in recent years. But it is difficult to believe that the export sector in these economies expanded throughout the 1960s in the face of persistent, large declines in profit margins. ${ }^{14}$

Government export subsidies are another potential explanation that is implausible in view of the persistence of these price trends. In Germany, for example, from 1961 to 1973 the export price index for manufactured goods declined 15 percent relative to the wholesale price index for manufactured goods. A subsidy of 15 percent to manufactured goods exports would amount to 2.6 percent of the German GNP or 14.5 percent of government expenditures in 1973.

A more reasonable explanation is that the cost data are poor reflections of the costs of manufacturing the particular commodities that are exported. According to this hypothesis, actual unit costs for export goods

12. "Estimated Hourly Compensation of Production Workers in Manufacturing: Twelve Countries, 1975-1977 and Eight Countries, 1978" (Bureau of Labor Statistics, Office of Productivity and Technology, October 1978).

13. For a complete discussion of the relative strengths and weakness of available competitive indicators, see Irving B. Kravis and Robert E. Lipsey, Price Competitiveness in World Trade, Studies in International Economic Relations, 6 (National Bureau of Economic Research, 1971), pp. 3-194.

14. The estimates of expansion in domestic export supply relative to income obtained by Goldstein and Khan are 5.6 for Germany, 3.25 for Italy, and 2.6 for Japan. See Morris Goldstein and Mohsin S. Khan, "The Supply and Demand for Exports: A Simultaneous Approach," Review of Economics and Statistics, vol. 60 (May 1978), pp. 275-86. 
have risen less rapidly than those in other industries, and export firms have therefore been able to lower their relative prices while at the same time expand profitably. Either productivity growth in the "export sectors" of these economies has been considerably more rapid than productivity growth in the rest of manufacturing, or the export industries have made relatively intensive use of a factor of production that has experienced a decline in relative price. ${ }^{15}$

\section{A Disaggregated Analysis}

In principle it should be possible to show by a disaggregated analysis whether costs of export products have risen less rapidly than those of other manufactured products. In practice, however, if export products are widely dispersed across firms and industries or if they are qualitatively different from products sold domestically, it will be difficult to obtain sufficiently disaggregated data to serve as a useful proxy for export costs. Where export products are concentrated in a few industries and where those product costs are similar to those sold domestically from the same industry, disaggregation by industry can be used to estimate export costs. In this section I report the results of disaggregation carried out under the assumption that export products and domestic products from the same

15. International economists have often stressed the "dualistic nature" of modern economies, although in doing so they have usually emphasized the distinction between traded and nontraded goods. Balassa developed this distinction in his reappraisal of the theory of purchasing power parity. See Bela Balassa, "The PurchasingPower Parity Doctrine: A Reappraisal," Journal of Political Economy, vol. 72 (December 1964), pp. 584-96. The Scandinavian theory of inflation relies upon a similar dualism in its account of the international transmission of inflation. See, for example, Odd Aukrust, "Inflation in the Open Economy: A Norwegian Model," in Lawrence B. Krause and Walter S. Salant, eds., Worldwide Inflation: Theory and Recent Experience (Brookings Institution, 1977), pp. 107-66. Haberler explained the marked disparity between the Japanese consumer price and wholesale and export prices in terms of the different productivity growth rates between goods and service sectors. See Gottfried Haberler, "International Aspects of U.S. Inflation," in Phillip Cagan and others, A New Look at Inflation: Economic Policy in the Early 1970s (American Enterprise Institute, 1973), pp. 91-92. See also Ronald I. McKinnon, Monetary Theory and Controlled Flexibility in the Foreign Exchanges, Essays in International Finance, 84 (Princeton University Press, International Finance Section, 1971), pp. 21-27. However, in modeling trade behavior, international economists have typically assumed that data for the manufacturing sector were appropriate indicators of costs in industries competing in exports and imports. 
industry have similar costs, but that costs differ across industries. Under this assumption, the appropriate aggregate cost index for manufactured exports is obtained by a simple reweighting of industry costs. ${ }^{16}$

\section{JAPAN}

Table 4 presents the result of reweighting cost data for individual Japanese industries by their export shares. For each industry, unit labor cost, unit value added, and total unit value indexes were derived by dividing the series on labor compensation, net value added, and gross value of output by the industrial production index. These series were then weighted by the 1970 share of each industry in Japanese exports, and the ratio of each to the corresponding series for total Japanese manufacturing was computed. The results indicate that the costs in Japanese industries with a large export share increased much more slowly than those in total Japanese manufacturing, reflecting the dualism that I hypothesize as the explanation for the results of tables 1 and $2 .{ }^{17}$

The first three columns of table 4 indicate that during the 1963-76 period, when weighted by export shares, unit labor costs, unit value added, and total unit values all declined relative to the corresponding measures for total manufacturing by roughly 20 percent. Moreover, as column 4 indicates, in contrast to the strong downward movement in the ratio of export prices to costs in manufacturing obtained in table 2, manufacturing unit values weighted by industry export shares are consistent with export unit values for the 1963-71 period. Increasing export subsidies, declining profit margins in export sales, or measurement errors

16. The disaggregation used data available in United Nations, Yearbook of Industrial Statistics. This source provides time series data on industrial production; value added in producers' values; value of gross output; and wages, salaries and supplements for three-digit International-Standard-Industrial-Classification (ISIC) manufacturing in several countries. Not all the series are available for each major industrial country, and for some countries certain series had to be aggregated or reweighted. These data were matched with export data classified by the StandardInternational-Trade-Classification (SITC). Most industries in the three-digit ISIC classification do correspond in a rough way to two- or three-digit categories in the SITC data, but the matching is not perfect.

17. The dualism referred to here is somewhat different from that which has been widely recognized in Japan. The latter refers to the coexistence of a "large-firm seetor" that has high wages and enjoys access to cheap capital, and a "small-firm sector," in which wages are lower and capital more expensive. 
Table 4. Ratio of Export-Weighted to Unweighted Unit Labor Costs, Unit Value Added, and Total Unit Values, and of Export Prices to Export-Weighted Total Unit Values for Japanese Manufacturing, 1963-76a

Index, $1970=100$

\begin{tabular}{|c|c|c|c|c|}
\hline \multirow[b]{2}{*}{ Year } & \multicolumn{3}{|c|}{ Ratio of export-weighted to unweighted index } & \multirow{2}{*}{$\begin{array}{l}\text { Ratio of export } \\
\text { price to export- } \\
\text { weighted total } \\
\text { unit-value index } \\
\text { (4) }\end{array}$} \\
\hline & $\begin{array}{l}\text { Unit } \\
\text { labor costs } \\
\quad(1)\end{array}$ & $\begin{array}{l}\text { Unit } \\
\text { value added } \\
\text { (2) }\end{array}$ & $\begin{array}{l}\text { Total } \\
\text { unit values } \\
\text { (3) }\end{array}$ & \\
\hline 1963 & 112 & 111 & 108 & 98 \\
\hline 1964 & 107 & 108 & 105 & 98 \\
\hline 1965 & 105 & 104 & 104 & 97 \\
\hline 1966 & 102 & 103 & 100 & 96 \\
\hline 1967 & 102 & 104 & 100 & 98 \\
\hline 1968 & 100 & 98 & 102 & 98 \\
\hline 1969 & 101 & 99 & 100 & 100 \\
\hline 1970 & 100 & 100 & 100 & 100 \\
\hline 1971 & 98 & 93 & 99 & 102 \\
\hline 1972 & 98 & 96 & 98 & 95 \\
\hline 1973 & 95 & 102 & 97 & 93 \\
\hline 1974 & 92 & 98 & 92 & 104 \\
\hline 1975 & 92 & 84 & 90 & 96 \\
\hline 1976 & 86 & 90 & 90 & 92 \\
\hline
\end{tabular}

Sources: The elata for 1970 Japanese exports are taken from United Nations, Yearbook of International Trade Statistics: 1971 Edition. Unit labor costs for total manufacturing were provided by the Bureau of Labor Statistics. The deflator for total manufacturing (value added) was supplied by Michael Deppler of the International Monetary Fund. All other data are from U.N., Yearbook of Industrial Statistics, vol. 1: General Industrial Statistics, various issues, tables 4, 9, and 13.

a. The components of the series on unit labor costs were derived by dividing "wages and salaries of employees" for each industry by the corresponding industrial production index. Similarly, the series on unit value added and total unit values were derived by dividing "value added" and "gross output," respectively, for each industry by the corresponding industrial production indexes. The food products, tobacco, petroleum refineries, and coal products industries were excluded to make the series conform to the data on Japanese exports. Each component industry was then weighted by its share in Japanese exports in 1970. The series presented are the ratio of the export-weighted series to the corresponding (unweighted) series for total Japanese manufacturing. The export price series is the ratio of the unit value index for manufactured goods exports to export-weighted total unit values in manufacturing (the ratio of gross value of output to industrial production).

can be eliminated as explanations for the downward trend in export prices relative to total manufacturing. Changes in export product prices reflected the changes in the costs of the industries in which they were produced.

As might be expected, exchange rate modifications and cyclical developments in the 1970s have changed export prices relative to costs. The decline in the ratio of export prices to total unit values (column 4) in 1972 and 1973 followed the appreciation of the yen under the Smithsonian agreement in December 1971, while the depreciation of the yen in 
1974 moved the ratio in the opposite direction. In 1975 and 1976, Japanese exporters used foreign markets to increase their capacity utilization, and again prices declined relative to total costs.

Reweighting industry costs by their export shares assumes that export and industry-wide cost movements are similar. To explore the extent to which export prices have displayed any trend relative to their domestic counterparts within particular industries, the components of the Japanese export price index were matched with the corresponding components of the Japanese wholesale price index. The estimated annual percentage trends in the relative export prices over the 1962-77 period are as follows. ${ }^{18}$

\begin{tabular}{lc}
\multicolumn{1}{c}{ Industry } & Export price trend \\
Chemicals & -1.3 \\
& $(-2.9)$ \\
Electrical machinery & -0.2 \\
& $(-1.4)$ \\
General machinery and & -1.5 \\
precision instruments & $(-6.3)$ \\
Metals and related products & -0.5 \\
& $(-1.6)$ \\
Textiles & -2.1 \\
& $(-8.8)$ \\
Transport equipment & 2.8 \\
& $(10.6)$
\end{tabular}

Statistically significant downward trends are evident in three relative prices; downward trends that were not significant, in two; and a significant upward trend, in one. At the industry level, therefore, there is evidence of a disparity in the trend behavior of domestic and foreign prices.

In summary, by appropriately matching the costs in a particular Japanese industry with export prices for that industry, much of the puzzle in the movement of Japanese export prices can be explained. However, to obtain a precise estimate of the true costs facing export firms, it will probably be necessary to disaggregate beyond the industry level because, in

18. Here, as elsewhere in this report, the $t$-statistics are in parentheses. The data used in estimating the trends are from various issues of the Bank of Japan, Economic Statistics Annual, and the Bank of Japan, Price Indexes Annual. 
certain sectors, downward trends remain when industry export prices are matched with industry wholesale prices.

\section{OTHER COUNTRIES}

For Germany, Italy, and France, the remaining countries in which negative trends were evident in the ratios of export prices to manufacturing industry costs, a reweighting of industry unit costs by export shares failed to confirm the results reported for Japan in table 4. Explaining the costprice puzzle in these countries will require considerable investment in the generation of a new data base.

A time trend like that found in the aggregate regressions of table 2 showed up in disaggregated regressions explaining export prices of nonelectrical machinery, which accounted for 23 percent of exports of German manufactured goods in 1976. For this trade category, actual export price series based upon contract prices are available for both Germany and the United States. It is therefore an ideal candidate for examining whether a significant dualism is evident within a particular German industry. Without a time trend variable, the residuals exhibit strong serial correlation. When the time trend is added, the serial correlation is eliminated, the standard error of the equation improves, and the $t$-statistic of all the estimated coefficients also improves. For the United States, reweighting was carried out based both on export shares and import-competing shares in different industries. Relative to all manufacturing, costs and prices in the export sector declined slightly between 1954 and 1977, while they rose slightly in the import-competing sector. But these trends were only on the order of 0.1 percent a year.

\section{IMPLICATIONS}

In summary, this exploration of dualism by calculating and reweighting industry costs has met with mixed results. In Japan, it is evident that the industries with large shares in Japanese exports are also those that have relatively slower increases in costs. For the United States, the reweighting exercise indicated small differences when industry costs are reweighted, a result consistent with aggregate data; while in the cases of France, Germany, and Italy, I was unable to find evidence of significant differences, which leaves the aggregate results unexplained. Because I was able to di- 
vide the manufacturing sector into only twelve "industries," a more precise disaggregation might meet with more success. However, even at the level of the nonelectrical machinery industry in Germany, costs for export products have apparently declined relative to costs for output in general.

These findings are important for model builders. In representing the supply side, extreme caution should be used when treating costs in manufacturing in general as a proxy for costs in the "export sector." Although the use of some variable with a strong time trend could provide an equation with a good statistical fit, the coefficients on such a variable would be biased. Before the determinants of relative costs in international trade can be analyzed, a considerable degree of disaggregation is needed.

\section{U.S. Competitiveness}

Because foreign manufactured exports compete with U.S. products both in the United States and in third-world markets, changes in their prices relative to those of U.S. manufactured goods are the major determinant of U.S. international price competitiveness. ${ }^{19}$ And because of the declining price of exports relative to total manufactures in some countries - what I call dualism - and the absence of such a dualism in the United States, for U.S. products to maintain their international price competitiveness, the average price of its manufactured goods has had to rise less rapidly than the average in other countries.

The following equation summarizes this historic relationship for the 1962-78 period:

$$
P X=1.03+0.97 P W P \text {, }
$$

$$
\bar{R}^{2}=0.81 ; \text { standard error }=1.5 \text {; Durbin-Watson }=2.0,
$$

where $P X$ is the percentage change in the ratio of U.S. to foreign export unit values and $P W P$ the corresponding ratio of U.S. to foreign wholesale prices of manufactured goods. ${ }^{20}$ This equation implies that, if there were

19. U.S. exports will also compete with domestic manufactured goods in each foreign market.

20. The denominators in these two ratios are a weighted average taken from thirteen industrial countries. For a detailed description, see International Monetary Fund, International Financial Statistics, vol. 32 (March 1979), p. 416. Data are from ibid., various issues. 
no change in relative U.S. wholesale prices, relative U.S. export prices would have increased at an annual rate of 1.03 percentage points per year. For relative U.S. export prices to have remained constant, the relative prices of manufactured goods would have had to decline by 1.06 percentage points a year. The relationships summarized by the regression remain apparent in recent data. In 1978, for example, U.S. relative export unit values were roughly at their 1975 levels despite a 6 percent decline in the relative price of U.S. manufactures between the two years.

Like the Houthakker-Magee effect discussed at the outset of this paper, the equation relating relative export prices and relative wholesale prices should be interpreted as a statistical summary of a historic relationship. The historical divergence between these two endogenous variables is an important fact underlying the declining competitive position of the United States. Just as the Houthakker-Magee effect predicts that equal growth rates here and abroad will lead to a declining U.S. trade balance, this equation predicts that equal inflation in manufactured goods prices here and abroad will also lead to a declining trade balance.

The dualism between prices of exports and all manufactured goods in the rest of the world explains why indicators of prices and costs in manufacturing have not provided an accurate picture of U.S. price competitiveness. This report has drawn attention to this disparity between costs in export and other industries in certain foreign economies. Further research is needed to determine the contribution of factors such as economies of scale, technological imitation, embodied technical change, and changes in factor endowments as causes of these disparities, and to determine whether these disparities will persist.

\section{Discussion}

MUCH OF THE DISCUSSION focused on what might explain exceptional productivity gains in export industries. Marina Whitman suggested that, even if subsidies did not directly explain the differential price performance of export industries, they could play a role indirectly by allowing export industries to reach their technological potential and to achieve sufficient economies of scale. James Duesenberry described two distinct situations 
that might give rise to exceptional productivity growth in some industries. In the first, countries may have developed industries or products that are growing rapidly in world markets. The interesting question in this case is what characteristics of a country permit it to gain leadership in those new industries. In the second, a country may have a latent comparative advantage in an established product that it utilizes increasingly over time to expand its production and world market share. Both situations involve an interaction of scale effects, demand growth, and technical change, and may well include subsidies and protection, at least initially. He doubted that one could understand these developments by estimating models with fixed coefficients and technologies. William Nordhaus added that the differential productivity growth among a country's industries would determine its exports. The differentials could be inherent in the country's basic human and physical resources. The wider these differentials, the more apparent would be the duality that Lawrence identified.

Robin Marris hypothesized that similar technological dynamics apply both to the successful export performance of other countries and to the failure of U.S. exports to expand. This dynamism produces an S-shaped growth curve; although technological catch-up is one element of the steep portion of this curve, other qualitative characteristics of economies are involved that are difficult to model. The United States is past this steep portion, while countries exporting to it are not. Some developing countries may now be in this phase, supplanting European economies whose exports expanded so much during the past two decades.

Rudiger Dornbusch emphasized the importance for policy formulation of sorting out the reasons behind the erosion in U.S. competitiveness. The conventional import demand equation implies we need to slow growth and control domestic inflation in order to improve the current account. By contrast, if the differences in productivity growth are due to economies of scale or to the opening of new markets for new products, channeling resources into expansion and research and development might be a superior policy to slowing growth or controlling wages.

Peter Kenen noted that the dualism hypothesis was most evident in the data for Japan and was more difficult to identify for other countries. This led him to hypothesize an explanation rooted in the institutions of the Japanese economy. There, the home market is so thoroughly sheltered from competition that it provides a high margin of profits for Japanese producers; this, in turn, provides an implicit subsidy for exports and 
permits Japanese producers to operate with low or variable profits at the margin in their export business. The dualism hypothesis may thus apply mainly to Japan and may reflect the peculiar characteristics of the Japanese home market more than it does other differences between the U.S. economy and its trading partners. Lawrence responded that, although he had been unable to provide disaggregated evidence for other countries, the strength and significance of the downward trends in their export prices relative to their prices for all manufactures could not be ignored. Also the dualism effect was apparent in the equation at the end of the paper, which used data from thirteen industrial countries; this showed that dualism was not a uniquely Japanese phenomenon. 